\title{
NOTAS SOBRE LO CURSI
}

\section{Por Francisco de la Maza}

En el año de 1869, el Diccionario de la Real Academia admitía por primera vez en el vocabulario castellano la palabra Cursi con esta definición: "Que presume de fino sin serlo; ridículo; de mal gusto."

Poco después, en 1875, el novelista Pedro Antonio de Alarcón intentó dilucidar su significado personificando lo cursi en la Gregoria de $E l$ Escándalo. "Gregoria era el tipo de la mujer presuntuosa, afectada, dominante; una buena moza muy vulgar, infatuada con una virtud más vulgar todavia: una marisabidilla de pueblo, echándola de madrileña culta y elegante; una necia, propensa al drama, rebosando insuficiencia a cada paso y que parecía provocar a todo el mundo a competir con su honradez, con su hermosura y con su ingenio, era, en fin, lo que sólo puede definirse en un vocablo provincial cuyo significado es. . . lo cursi." Mas ni la Academia ni Alarcón han definido lo Cursi; se han acercado a ello solamente.

Don Jacinto Benavente llevó al teatro la palabra y la actitud y en 1920 escribió su comedia "Lo Cursi", una de sus obras más débiles, por cierto. La dedicó, no sé por qué, a don Benito Pérez Galdós, que nunca tuvo el menor asomo de cursi. Benavente no comprendió lo cursi. Le parece que ese concepto es dañino a la sociedad. En la escena IV del acto I hace decir a un marqués: "La invención de la palabra Cursi complicó horriblemente la vida; antes existían lo bueno y lo malo, lo divertido y lo aburrido y a ello se ajustaba nuestra conducta. Ahora existe lo cursi, que no es lo bueno ni lo malo, ni lo que divierte ni lo que aburre; es... una negación; es lo contrario de lo distinguido; es decir, una cosa cada día, porque en cuanto hay seis personas que piensan o hacen lo mismo, ya es preciso pensar o hacer otra cosa para ser distinguido y, por huir de lo cursi, se hacen tonterías, extravagancias ... hasta maldades." El hijo del marqués le pregunta: "¿maldades?" "Sf - responde- porque maldad es disfrazar los sentimientos y, por no parecer cursi, los disfrazamos muchas veces y obligamos a los demás a disfrazarlos... sabré yo por qué digo las cosas."

$\mathrm{Y}$ esto era lo que le dolía a don Jacinto, el creer que por huir de ese invento de lo Cursi, hasta malas se volvian algunas personas. Debió existir por esa época un miedo cerval a aparecer cursi, época, por cierto que se ha significado como una de las más cursis de la historia. Algo atisba, sin embargo, cuando se refiere a que es lo contrario de lo distinguido, 
pero se queda, como Alarcón, en la espuma del problema, sin llegar al fondo.

Se necesitaba un espíritu más sensible, más abierto y más fino para situar y comprender lo Cursi. Fue Federico García Lorca, quien decía confidencialmente una ve a un amigo: "No lo digas, pero me encanta la mala música." En la obra teatral Rosita la soltera o el lenguaje de las flores exhibe, con ternura y simpatía, con toda comprensión, esa especial actitud vital que llamamos lo Cursi. Rosita es la encarnación de lo Cursi en su aspecto más fino y delicioso. Todo cuanto dicen ella y "las tres solteras cursilonas", es justamente lo Cursi. En un parlamento dice Rosita unos versos que son la exacta transcripción poética de una de esas tarjetas postales que son la suma y el zumo de lo Cursi:

Una noche, adormilada,
en mi balcón de jazmines,
vi bajar dos querubines
a una rosa enamorada;
ella se puso encarnada,
siendo blanco su color,
pero como tierna flor,
sus pétalos encendidos
se fueron cayendo heridos
por el beso del amor.
Así, yo, primo inocente,
en mi jardín de arrayanes
daba al aire mis afanes
y mi blancura a la fuente.
Tierna gacela imprudente
alcé los ojos, te vi
y en mi corazón senti
agujas extremecidas
que me están abriendo heridas
rojas como el alhelí.

Y cuando al primo, que es el novio, promete volver de América, le pregunta:

¿Qué paloma iluminada

me anunciard tu llegada?

El responde:

El palomo de mi fe. 
Y Rosita concluye:

\author{
Mira que yo bordarc \\ sábanas para los dos.
}

Sueños, flores, balcones, palomas, querubines que se posan en flores... toda la esencia de lo Cursi. Y así es toda la tragedia, que no comedia, del poeta granadino.

García Lorca nos dio la imagen poética de la actitud cursi, pero no la definición, no esa difícil síntesis en pocas y precisas palabras que es una definición. Para ello se necesitaba un filósofo. $Y$ fue un humanista mexicano, el fino e inteligente escritor Antonio Gómez Robledo quien, con todo rigor filosófico, con toda profundidad y comprensión, definió lo Cursi, de manera perfecta, en dos palabras: LO EXQUISITO FALLIDO.

$Y$ eso es, en efecto. Lo Cursi es "el quiero y no puedo". Es el querer llegar a las cumbres de lo elegante y de lo distinguido y quedarse a la mitad; pero, por supuesto, creyendo haber llegado, pues una de las características esenciales de lo Cursi, de esa falla de lo exquisito, es la sinceridad. Veamos algunos ejemplos de todas índoles y extraigamos de ellos sus consecuencias.

Famosas, por cursis, son las tarjetas postales de amor, de felicitación por el santo o por el cumpleaños o para felicitar a las mamás en esa fiesta esencial de la cursilería que es el invento del "día de la madre". Las tarjetas de novios son siempre un par de jóvenes guapos, tiernos, rebosantes de felicidad, que se dan flores o cartas de amor; muchas veces se contemplan arrobados mientras sobre sus cabezas revuela una paloma - símbolo de la castidad y de la fidelidad- que lleva en su pico la carta de amor o un corazón atravesado por un dardo que sangra flores. El amor, para los cursis, es esa continuidad romántica de los amoríos adolescentes, sin que nada empañe el encanto, sin que nada perturbe los sentimientos, siempre los mismos. Lo Cursi es casto, o cuando menos honesto y desconoce pudorosamente cuanto pueda conducir a algo indecoroso en el amor.

Cuando representa a Ia familia es siempre con un joven padre pul. cramente vestido y una madre no menos joven y hermosa, rodeados de lo que sería la ilusión de los matrimonios: tres lindos hijitos, uno, el mayorcito y heredero, peinado y relamido, y dos más pequeños, niño y 
niña, festivamente vestidos y con flores en las manos. No falla nunca, por ejemplo, que los calcetines sean siempre blancos, así como los trajes, que de vez en cuando se permiten azul celeste o color de rosa. A veces la familia viene desde la abuelita - nunca he visto una tarjeta postal con abuelito, tal vez por ser menos tierno todo varón- que es una "cabecita blanca" para usar la acuñada frase cursi de nuestros cursis periodistas y maestros de escuela. A estas tarjetas acompañan "poemas" que sintetizan y complementan los sentimientos populares de quienes las fabrican para el consumo de los cursis. Los ejemplos son por millares:

$$
\begin{aligned}
& \text { Mi lenguaje no traduce } \\
& \text { lo que siente el corazón; } \\
& \text { sólo con veneración } \\
& \text { ¿Madre!, su voz reproduce }
\end{aligned}
$$

o csta increíble cuarteta:

$$
\begin{aligned}
& \text { Mamacita, con ternura, } \\
& \text { te ofrecemos estas flores; } \\
& \text { admiramos tu hermosura, } \\
& \text { te damos nuestros amores. }
\end{aligned}
$$

y esta otra que es ya inefable:

$$
\begin{aligned}
& \text { Linda, linda mamacita, } \\
& \text { tú eres buena para mí } \\
& \text { yo soy todo para ti } \\
& \text { [Cuán dulce es tu sonrisita! }
\end{aligned}
$$

En la poesia lírica de todas las naciones, sobre todo en los poetas populares o, como cursimente se dice: de "los bardos callejeros", existe una buena dosis de cursilería; y no se escapan a ella muchos poetas conocidos y hasta "consagrados". ¿Quién puede negar que sea cursi un Antonio Plaza, a pesar de su tragedia o "el cantor del hogar" don Juan de Dios Peza o Manuel Acuña? Lo mismo pasa en las novelitas de amor que el certero sentido común llama "novelas rosas" o hasta en famosas mundialmente conocidas como Pablo y Virginia, de Saint Pierre. Hay en ella escenas como ésta: "Virginia, deshecha en llanto, oprimía alternativamente contra sus labios y contra su corazón las manos de su madre y las de Margarita." ¿Se imagina el lector esa dolorosa escena en la cual "alternativamente", es decir, unas primero y otras después, subían y baja- 
ban, de los labios al pecho, las cuatro manos de la mamá de Virginia y de su amigar $\mathrm{Y}$ así podríamos poner docenas de ejemplos.

Pero más allá de las tarjetas postales y de la literatura barata, la cursileria se encuentra en todas partes, haciendo acto de presencia desde en las intimidades de las alcobas hasta en las fachadas de las casas. Esas pinturas de las señoras "aficionadas" que copian tiernamente tiestos dc flores, imágenes de santos, paisajes, escenas médicas para los consultorios o cuadros "célebres" (que siempre son obras del romanticismo), son buenos ejemplos de la femenina cursilería del hogar, a veces de una ternura que conmueve, porque así como lo cursi es moralista y quiere ser elegante, también es dulce y conmovedor. Los tejidos policromados o los bordados con pierrots y colombinas; los relojes de mesa, desde el siglo xvin; los grupos de porcelana o de bronce con personajes que tocan el piano o bailan un minué; esos globos y jarrones donde niños desnudos, coronados de rosas, trepan por exúberas vides; esos platos, en fin, con dioses griegos o escenas de caza medieval, llenan con su discreta cusilería lo que en los palacios son buenas pinturas y esculturas o en las casas proletarias estampas de santos o fotografías de divas de ópera y teatro o efébicos artistas de cine.

La juguetería mundial es uno de los máximos ejemplos de lo Cursi. El inventor de juguetes -salvo excepciones admirables- es un cursi. Reduce el mundo a miniatura, lo hace tierno y simple, amoroso y dulce y nos lanza esos elefantitos de todos colores y en todas posturas; esos gatitos y perritos inverosímiles; esas casitas de muñecas con todos sus enseres y, en fin, todos los bibelots siempre cursis, desde una señora estilo pompadur, galanteada por un jovencito de peluca blanca, hasta esas copas con orlas de encaje en los bordes sostenidas por manos largas y delgadas con anillos de claveles o de rosas, o los botines del año de 1900 en los que cabalgan amorcillos.

$Y$ hay toda una arquitectura cursi de primer orden. Cuando un recién enriquecido burgués quiere tener su casa propia, escoge a un dócil ingeniero o arquitecto (?) para que le haga su "nido colonial" y el ingeniero, experto ya en esas modas, copia una ventana de la parroquia de Taxco; la puerta es una imitación, más rica y más barroca de Valenciana o Tepozotlán y el garage es toda una capilla con azulejos estilo poblano. El escritorio del señor es "estilo" colonial, lleno de relieves que nunca se usaron en la Nueva España y con un escudo nobiliario copiado de algún libro de heráldica. Lo único que disuena es el teléfono, que se resigna a mostrar su modernidad junto a un cartapacio florentino con las flores 
de lis de los Médicis y un jarrón de estilo Luis XV. Sólo conozco por fuera la casa del señor Elías Henaine, pero con esas fachadas basta para ejemplificar la cursilería por excelencia. Mas hay algo todavía peor: en la calle de Anatole France 84, una casa compone su fachada de relieves y csculturas con monstruos y animales, monjes llorosos como los de la tumba del duque de Borgoña, y las gárgolas de Notre Dame hacen su triunfal aparición entre hojarascas y volutas estilo... ¿Luis XVII! ${ }^{1}$

Mas lo cursi es toda una actitud vital que es necesario comprender. Cursi es el ensueño diario de la humanidad que se imagina mejor de lo que es, elevánclose por la imaginación a deseadas categorfas imposibles de cumplir. El ensueño de la mesera que se imagina casada con el más guapo de los comensales a quien diariamente sirve; el ensueño del chofer de llevar en su automóvil a princesas suculentas; el ensueño del cartero que imagina novelitas cortas con los nombres que le atraen en los sobres; el ensueño del sacerdote de que permanezcan siempre puros los niños a quienes ha dado la primera comunión; el ensueño de la solterona de que se diga que su intocado cuerpo es más hermoso que el de las madres fecundas; el ensueño de todos, viéndose en oníricas representaciones en un estado de bienestar digno de envidia; el "si fuera rey" o "si fuera millonario", todo eso es cursi. Todo sueño despierto es cursi porque es la búsqueda de lo exquisito, de lo bello, de lo grande, inalcanzable. Pero todo sueño es necesario como válvula de escape, como huida fácil, pero profunda y necesaria, de la cotidiana y triste realidad, más llena de espinas que de flores, para decirlo con una frase deliciosamente cursi.

Dice bien Ramón Gómez de la Serna: "lo cursi nace de la conformidad de vivir y morir en unos setenta años y por eso agarra el alma humana y acierta con la intimidad que hay que dar a cada cosa". ¡Ay del que no tenga algo cursi alguna vez en su vidal "Si tienes un hueco en tu corazón llénalo de amor", dijo cursi y verdaderamente el verdaderamente cursi Amado Nervo. Yo diría: "Si tienes un hueco en tu corazón, llénalo de cursilerfa." 2

1 Añadimos ahora dos cjemplos inefables de cursileria arquitectónica, de malísima cursilería arquitectónica, uno yanqui y otro mexicano: el primero es el The World's Corniest Building, del pueblo de Mitchell, en Dakota, con cúpulas "bizantinas" y minaretes "estilo Gaudi" (según ellos) y escenas de caza, de ladrillo, en los entrepanos. El segundo es la Catedral de Acapulco, del arquitecto Federico Mariscal, también "bizantina", con azulejos de azul marino y torres "chinescas". [Estambul y Manila. el Oriente de la nao de la China, todo en un "simbolo" arrojado en una Catedrall

2 Estas Notas fueron publicadas en la revista Cuadernos Médicos, tomo II, núm. 3, diciembre de 1956, México. Esta revista no fue venal y está agotada. Las Notas fueron un resumen de la conferencia "Lo Cursi como categoría estética", dada en la Socie- 


\section{APÉNDICES}

\section{CURSILERIA RELIGIOSA}

Haly cuatro actitudes o grados que el espíritu humano desarrolla ante lo divino: la mística; la ascética; la devoción y la superstición. Sólo una cle ellas puede ser cursi: la tercera.

Por su grandeza y elevación no podrían ser las dos primeras. Por su degradación, tampoco la cuarta.

La mística es un fenómeno individual, como lo es el genio en el arte o la ciencia, o el héroe en la historia. No se es místico por voluntad, ni aun por sola lia gracia. Para los teólogos, el místico es un elegido; para los psicólogos, un desarrollo especial de la mente hacia el misterio trascendente. El mistico no está en la realidad; no desea ni necesita de objetos sensibles para su unión con lo divino.

El asceta aspira y logra la misma meta, pero con ayuda de lo real y sensible. Si el místico se arrebata en Dios; el asceta lo hace en Cristo, forma tangible y humana. El místico es contemplativo; el asceta, activo.

El devoto necesita de la ayuda externa para acercarse a lo divino; crea el diálogo con Dios, le pide y amonesta, le suplica, lo emplaza. Necesita del "retrato" de Dios, de la Virgen, de los santos, de las almas. El asceta admite las imágenes; el devoto las necesita absolutamente. Dos palos cruzados bastan al asceta para recordar la Redención; el devoto requiere la figura doliente del propio Cristo. Al asceta le basta el nombre; al devoto sólo le basta la imagen, y que sea clara, representativa, bonita o sugerente. Es la devoción la que crea las novenas, triduos, rosarios, viacrucis y demás "devociones". Se juntan los devotos en cofradías, gremios y aun órdenes religiosas. Usan y abusan de los sacramentos y si San Francisco de Asís, el trovador de Dios, no se confesaba, San Francisco de Sales, el sacristán de Dios, lo hacía con frecuencia.

Es la devoción la autora de la imaginería doméstica. La devoción ha creado la "primera comunión", las misas de quince años y las bodas de plata y de oro, las de graduaciones de bachilleres de gorros sajonoides. Es la devoción la que ha creado la "hora santa", las campanadas de "Nuestro Amo está solo", las "cuarenta horas" y la "adoración noctur-

dad de Arquitectos en febrero de 1956. Se añaden aquí tres párrafos más, uno sobre las estampas religiosas, otro sobre los calendarios comerciales y un artículo periodistico. 
na", así como al Sagrado Corazón de Jesús; el Sagrado Corazón de María; el "mes de María", el Niño de Atocha, el Perpetuo Socorro y el Pronto (!) Socorro.

Crea cantos litúrgicos de gusto atroz y deseos ingenuos. Decía un himno a Cristo "Eres hermoso, señal de eterna paz." Y la Eucaristía era "la paloma sedienta que vuela hacia ti".

Cristo, la Virgen y los santos son siempre bellos, o, más bien, bonitos. Cristo-Rey es un joven monarca, sentado en trono, con la corona imperial, en un cojín, a sus pies. Por pudor, a veces, rueda a un lado su verdadera corona: la de espinas. La Virgen es una guapa y dulce joven con manto, llena de joyas y vestidos de oro. Los santos son siempre hermosos, así sean ancianos y, con más razón, si son jóvenes. Desde un príncipe italiano, como Luis Gonzaga, a un mulato peruano, como Martín de Porres, la belleza juvenil ilumina sus rostros lampiños.

Todo esto se dice, por supuesto, de la imagineria a domicilio, comercial y barata. La obra de arte no tiene nada que ver con lo cursi.

Las estampas y retratos de primera comunión; los retratos de boda; las invitaciones de misas y fiesta de quince años, son cursis. $Y$ de lo cursi malo. Se inventan trajes para las primeras comuniones.

De fines del siglo pasado hasta los treintas, los trajes de los niños comulgantes eran los de moda, pero en blanco. Las niñas siempre de largo y con velo y corona. Después vistieron a los muchachitos de acólitos, cle frailes, de caballeritos del Santo Sepulcro. O de etiqueta varonil. Las niñas fueron de monjas o de damas antiguas.

Las estampas impresas a colores son variadas. Un fino, joven y guapo sacerdote da la Hostia al aún más fino y hermoso niño. Además, siempre con buenas y aun costosas ropas. A veces es un obispo, con mitra y capa pluvial. Otras es el propio Cristo quien da la comunión. "¿Qué es comulgar?", enseñan las monjas y el niño debe contestar: "Recibir a Dios en mi corazoncito."

Los pasteles de comunión, con su cáliz dorado y su hostia o los propios niños en simpáticas esculturas de azúcar; los pasteles de boda con sus muñecos-novios, son esencia y presencia de la más profunda cursileria.

Las representaciones de Cristo como niño y las muy escasas de adolescente son siempre exquisitamente, refinadamente cursis. Caritas sonrosadas, de ensortijados cabellos rubios, con ojos grandes, húmedos, de pupilas azules o café claro dorado, son siempre los Niños-Dios y los ángeles de estampas y nacimientos.

El ángel barroco, nunca cursi, arriesgaba su belleza y su desnudez 
en un idealismo que, trasnochado, deriva del ethos clásico. El ángel cursi va honestamente vestido de largo si es jovencito; honestamente desnudo si es niño, es decir, con su fajilla blanca o dorada sobre el sexo o las nalgas.

Las expresiones son de azoro y de felicidad en los rostros; de inocencia e ingenuidad que llegan al hastío. Los ademanes son de baile, de opereta, pero de unción admirativa.

Los arrobamientos, en las figuras de santos, son, como diría Santa Teresa, "abobamientos", y los Cristos y Vírgenes, cuando sufren, lo hacen con recato y medida, con resignación, sin fruncir el ceño y descomponer el rostro. Cuando hay alegría la hay sin risa. Los dioses no ríen, porque la risa es demasiado humana. Habria que estudiar a fondo el porqué de la ausencia de la risa en los dioses de Grecia y en los santos cristianos. Las pocas excepciones, como siempre, confirman la regla.

Hay unas estampas grandes, que les llamamos "cromos", que representan alegorías religiosas. Una de ellas, cuyo origen ignoro, representa a "La Nueva Jerusalén", es decir, el Paraíso posterior al Juicio Final. En la parte superior está la Ciudad Celestial, con iglesias cupuladas y... templos clásicos con peristilos y techos a dos aguas. En el centro, en un nicho enorme, San Pedro, a quien adoran dos ángeles. Uno de ellos es San Miguel, vestido de soldado romano y con la espada flamígera. En el centro del cromo, en dos filas, una que asciende y otra que baja, catá la caminata de los elegidos y la de los réprobos. En el vértice de estos senderos, al lado izquierdo, Cristo en la cruz, a quien rodean una mujer, un monje, un mendigo, un rey y un obrero. De esta cruz parten los caminos. El del cielo se compone de unos recién casados, con todo y velas en la mano, él de levita; dos monjas, un presidiario de arcaica cadena que va de la mano al pie y que lee un papel; una Hermana de la Caridad con cuatro niñas; dos clérigos, un obispo, un acólito y luego una serie de figuras con túnicas blancas.

El camino de los condenados es más nutrido, variado y rico. Comienza con un avaro, y un suicida; luego un joven de frac que lleva un libro y rollos de papel, más una copa (?). En seguida un cazador o explorador, emborrachándose, ya que bebe con fruición de una botella. Este explorador va del brazo de una negrita, semidesnuda. (¿Por qué este recuerdo, en oprobio, de los exploradores de Africa? Claro que la mayoría fueron, a la vez, explotadores, pero no como para ejemplificar el pecado sin redención.) La cosa empeora después. Ya no son pecados, ya es modo de ser, o raza, pues son dos gitanos bailando (l). 
Y sigue en plan de injusticia y de peligrosa tontería: ahora son un músico, un juglar y un payaso. Esa parte tétrica, inhumana, antivital, de ciertas épocas del clero, está aquí monstruosamente presente. En el ángulo izquierdo un hombre asesina a un rico que lleva un costal de monedas.

Sigue una rubia dama muy desnuda, a modo de bailarina y luego dos elegantes mujeres con un caballero de frac y monóculo (1). Una de las damas lleva traje de baile de los años veintes y la otra es una bailarina de ballet, empinando una copa. A los pies del trio, unas barajas.

Viene luego una anciana del pueblo con bastón, que no tiene facha alguna para ir en el cortejo de Satanás; junto a ella un joven como bendiciendo y con una cruz. (¿Qué es eso? ¿El Protestantismo?) y luego otro joven con un relleno costal a la espalda, que tal vez es el hurto. Por último en plan de carcajada - de nosotros- "el mundo pagano", representado por el mahometismo, con un barbado sultán o visir y una guapa dama, con abanico, imontados en un horrible dragón de tres cabezas de hocicos ignífugos!

E1 ángulo derecho inferior es el infierno, con sus almas en llamas, su diablo casi negro que arrastra a dos muchachas, Ia muerte lanzando almitas desnudas, de cabeza, y Satanás en trono, con tridente y todo.

Tal es la visión, medieval, de esta cursilería religiosa que seguramente nunca convenció a nadie en ningún sentido.

\section{LOS CALENDARIOS}

Los calendarios han sido una fuente continuada e inagotable de auténtica cursilería. Ignoro la fecha, el año exacto en que comenzaron a publicarse, pero creo que su desarrollo máximo, en plan cursi, fue a partir de los treintas. Tal vez algún curioso tenga una colección de ellos, pero lo cierto es que, al cambiarse cada año, se tiran a la basura los anteriores. Se usaban en los corredores de las casas, en las cocinas y, sobre todo, en las tiendas de miscelánea.

Las casas comerciales $e$ industriales han sido las proveedoras de esos policromados engendros ${ }^{3}$ y parece que cada firma comercial tiende a

3 Por supuesto que hay calendarios buenos, a veces copias de famosos cuadros. paisajes y aun retratos de niñas y niños siempre realmente bellos. 
superar en cursilería a sus competidores. El resultado es espléndido: el vio de lo cursi se engruesa, salta, forma cascadas de dulcificantes escenas y a mayor mal gusto, mayor éxito, en su doble sentido de triunfo y venta.

Todos los calendarios son cle pintura realista, académica en el sentido de querer pintar sus personajes muy bien dibujados y vestidos -0 en desnudo- y con un cuidado minucioso en los detalles. Todos son "bonitos", como las tarjetas postales o las estampas religiosas. Pero, al contrario de estos dos dechados de cursileria, los hay $-y$ los hubo más, hace años- de desnudos femeninos muy procaces, exagerando la libido las formas de las guapas modelos, todas imaginadas. Esos calendarios son típicos de cantinas, zapaterías, sastrerías, algunas tiendas pequeñas, algunos clubes y muchas recámaras de solteros de la clase baja.

Casi todos los calendarios van firmados, como si fueran una obra de arte, y sorprende encontrar docenas y docenas de nombres de pintores, a veces excelentes en el oficio, que se dedican a esta clase exclusiva de pintura ignorada por los criticos de "arte popular". Digo esto porque los críticos de arte en serio no pueden tomarlos en cuenta. ¿Pero son, incluso, arte popular? Por su fin y destino, por su aceptación en el vulgo, por sus temas y otras razones, lo son, pero no en su técnica ni en su falta de sinceridad (¿quién sabe?), que serian dos modos de ser del llamado "arte popular".

Arte cursi: eso son. Ni arte culto, ni popular, ni burgués, ni "popis", ni campesino, ni naïf. De todo eso tiene, pero no es todo eso. Es arte cursi, con esa categorfa estética especial que proclamé hace catorce años.

Por su tema podemos catalogar los calendarios en: patrióticos, religiosos, familiares, costumbristas, mitológicos, eróticos, de anuncios, de retratos y de ciertos sucesos históricos.

Rara vez tratan temas del año en que se hacen o de temas de interés contemporáneo. Para el cursi la vida es continua sucesión de felices deseos y de utópicas realidades. Aś es que las modas casi no aparecen; los grandes sucesos mundiales carecen de "atractivos", y los modelos y temas siguen siendo parecidos a los años anteriores. Algunas excepciories hay, claro está.

Los temas patrióticos son siempre políticos. El cura Hidalgo, Bolivar, Madero, son objeto de renovaciones cada dos o tres años. Nunca políticos vivientes. En general estos temas llevan símbolos o son tratados simbólicamente. El puro retrato del héroe parecería la fotografía oficial y obligada de las presidencias municipales, juzgados, escuelas y oficinas 
gubernamentales. No. El héroe debe ser inmortal y nimbado de gloria, como los santos.

Destacamos dos. El primero, con Bolívar como asunto. El pintor es A. Gómez R. El héroe venezolano, retocado y hermoseado el semblante, monta en un caballo blanco, casi plata, que nos mira fijamente con mirada humana, más inteligente y decidida que la del caudillo. Al fondo soldados y banderas. Una señorita, entre ángel, musa, bailarina y modelo de salón de belleza, vuela a su espalda; va vestida con túnica blanca y manto verde. Esta musa o victoria o fama o lo que sea, corona a Bolívar con una diadema de hojas que pretenden ser de laurel.

El segundo es el Cura Hidalgo, en apoteosis. También es el calendario una de las apoteosis más señeras de la cursilería. Está el anciano cura, de blanca, larga y alborotada cabellera, vestido con un especie de abrigo más abajo de la rodilla y con amplias y gruesas solapas; en el cuello, una camisa blanca pero con dos picos cafés, como los de las solapas. Calza botas y sus pies pisan una gruesísima cadena, tan gruesa y feroz, que resulta una ignominia para lo que representa, es decir, la Nueva España, el Virreinato, la Colonia, tres siglos de formación histórica que son, quiérase o no, nuestro pasado más vital, pues no vivimos, ahora, a la manera del otro pasado, el indigena, sino que vivimos nuestra incorporación a Europa, a la cultura occidental. La faja que cierra en su cintura al sobretodo, ése que no quiso ser sotana, es una preciosidad: es roja, anudada con escandalosa vuelta en el flanco derecho y con dos borlas doradas en las puntas. Esto es lo mismo que estofar a las esculturas de los santos.

La actitud es "heroica". Además de adelantar y subir un pie a una grada, levanta el brazo derecho y abre la mano en actitud histérica o demagógica, pidiendo algo al cielo, que subraya con la mirada a lo alto, fruncidas las cejas. Con su mano izquierda enarbola la Virgen de Guadalupe, la de Atotonilco, hecha un lábaro ya, con sus cenefas doradas arriba y en las puntas, que nunca tuvo. Una bien pintada paloma, que no podía faltar, revuela enfrente, abriendo sus alas enormes y la cola cn abanico. Pero lo más significativo y cursi es el ángel, un hermoso muchacho andrógino, de rizada y blanca cabellera - tan rubio, tan oxigenado es el pelo, que resulta blanco- vestido como musa romántica, con una túnica azulosa que le vuela por todas partes, a pesar de lo cual saca de aquel mar de gasa la pierna izquierda, desnuda hasta la ingle, fina y esbelta pierna que también se esforzaban en enseñarnos los ángeles barrocos. Este ángel cursi va a coronar al Padre de la Patria pero 
antes, en un tierno arrebato que nos conmueve, el joven alado se inclina y besa la frente del anciano $¡ \mathrm{Oh}$ emoción arrebatadora!

Los calendarios familiares son los más cercanos, como es natural, a las tarjetas postales del mismo tema. Pero casi siempre son de carácter "mexicano", aunque los tipos no sean los característicos. Es decir, son casi siempre criollos o figuras muy europeas, incluso de ojos azules, pero vestidos de charros, chinas poblanas, campesinos y hasta obreros. Para lo cursi, lo bonito o la belleza humana es siempre la blanca, rubia o castaña en general, sonrosada, de facciones finas y serenas, de expresión tierna. Las escenas son de deleitación ante los hijos niños; de reverencia a los padres o abuelos; de conversaciones o actitudes edificantes; siempre con el placer honesto reflejado en los rostros, que son de una deliciosa bobería y de una empalagosa dulzura.

Hay unos calendarios que me he decidido a llamarlos, sin convencerme, de "mitológicos". Es decir, que se ocupan de mitos, leyendas y símbolos, casi siempre indígenas. Por ejemplo "La mujer dormida" o sea el volcán Iztaccihuatl como una "india" dormida que parece una venus con peplo y un "indio" que la adora. O es "La raza de bronce", como un inefable calendario de los cincuentas en que su autor - por rareza no está firmado- pone a una hermosa pareja de "indios", que podian ser italianos, semidesnudos. El con un maxtlatl azul y, un copilli de metal con plumas, un collar con un tlaloc y gruesas pulseras de oro; ella con un pelo encrespado, rizado, suelto, con una cinta y un medallón con una pluma en la frente; lleva un maxtlatl (?) de colores y un manto que le trasluce los senos y le deja al descubierto el vientre y ambas piernas. El pisa, casi, una fogata y ella esconde sus pies con un ciervo muerto. Al fondo un lago azul, los volcanes y una luna que, por supuesto, irradia sus rayos en forma de cruz.

Hay uno, del pintor Angel Martín, que es inefable: es algo así como "El Mestizaje", la soñada y cursi "raza cósmica" vasconceliana; la unión de España y América en el siglo xvı, con bendición sacramental, naturalmente. Un fraile indefinible, pues lleva hábito blanco, escapulario corto con mangas y capucha color café y cordón y rosario colgando de la cintura. No es ni dominico, ni franciscano, ni carmelita pero algo de los tres 
tiene y más parece jerónimo, es decir, ya nadie. Eso sí, el libro que lleva en la mano es un códice (!).

Los novios son un conquistador que igual podría ser un vikingo, un inglés, un checo, de pelo rubio, barba corta y rizada y fino bigotillo a la siglo xix; lleva armadura en el torso, calzón corto de seda, medias cafés y botas con espuelas. Ella es la "india", morena clara, es cierto, pero de ojos enormes y rasgados, cejas depiladas, nariz griega, boca pequeña pero de labios gruesos y sensuales y tan alta como jamás ha habido una indigena americana.

Lleva copilli joh!, si bien de forma circular y gran copete de plumas verdes; las trenzas sobre el pecho, doble túnica talar -que se abre con coquetería de la rodilla para abajo- y joh sutileza! un velo transparente en lugar de rebozo con un ramo de flores en la mano.

Un caso de suprema cursilería es la de ciertas "reconstrucciones" históricas. Para el caso de los calendarios podemos recordar el de una carrera del circo romano en cuyo carro, tirado por tres vigorosos y alocados corceles, un negro, y dos blancos, el auriga no es él, sino ella (!), una delgada y guapa joven, semidesnuda, transparentando los senos, con capa al aire y... casco de soldado. La cursilería fina hubiera puesto un atleta; la cursilería barata - mexicana y muy "macha"- ha puesto a una niña que, en otro calendario, será la novia o la educanda de primera comunión.

En retratos hasta Sor Juana anda en la cursilería calendárica. Hay uno, de Manuel Piña $V$. en que la poetisa, con pintura facial de los treintas, es decir, ceja arqueada a fuerza, "chapas" rojas y boca de corazón, escribe el famoso poema "Hombres necios que acusáis a la mujer..." y arriba una "alegoría" o sea Cristo perdonando a la mujer adúltera.

\section{LO CAMP Y LO CURSI *}

Tres de nuestras plumas jóvenes, las de Carlos Fuentes, Carlos Monsiváis y Guillermo Piazza, han escrito al alimón un interesante y largo

\footnotetext{
4 Publicamos aquí un artículo aparecido en Novedades, Suplemento "México en la Cultura', del 10 de abril de 1966.
} 
estudio sobre lo "camp" en la revista Sicmpre de $\mathbf{3 0}$ de marzo de 1966.

Confesamos nuestra ignorancia de lo Camp antes de este estudio pero, según parece, proviene de la persona de Susan Sontag y su novela The Benefactor, así como Barbey D'Aurevilly sacó el bovarismo de Madame Bovary.

Es lo Camp una "nueva sensibilidad", una "nueva estética" y una nueva interpretación de la realidad. Nada menos.

Pero lo Camp es muchas cosas, tantas, que acaba por perderse en sa misma magnitud. Es lo pasado, pero no todo; es lo demodé, pero selecto; es algo de lo barroco y todo el Art-Nouveau; es mucho de lo cursi y casi todo el mal gusto; es lo "tan malo que resulta bueno"; es lo charro y lo chabacano; lo pedante y lo pedestre; lo vulgar y... todo lo que pueda ocurrirse a quien se ponga unos anteojos de manufactura y graduación óptica marca "camp".

Nos dice Carlos Fuentes que camp "es una visión del mundo a partir del estilo", pero no de toclo estilo, sino del "que ama lo exagerado, cuyo ejemplo máximo es el Art-Nouveau". Esto hace suponer que hay ejemplos mínimos que serían, por exagerados, la India y lo maya; el gótico florido y el barroco; una mitra episcopal y las tehuanas de Juchitán.

El Camp es lo "peligrosamente extravagante", como Gaudí o Wilde, pero también es lo banal que adquiere valor, es decir, pierde su banalidad con el tiempo, como sucederá a Oriol, Spota o Libertad Lamarque. Así que es cosa del tiempo, como la momificación. ¿El disparate flagrante del pasado se hará virtud y prudencia con lo Camp?

Eso y más, porque lo Camp es "la experiencia consistentemente estética del mundo". (Es interesante observar que, en este mundo actual del apócope y del anagrama; de lo sintético y la economía de lenguaje; del PRI y la CONCANACO; de la FBI y la OEA; del ISSSTE y de GDO, éste es el presidente de la República; antes fue ALM y no le tocó a Porfirio Díaz, si no hubiera sido PD; de los estilos POP y OP, la estética o una estética se llama CAMP. ¿Y por qué se le llama asi?)

Si es una "consistencia" estética, todo deviene Camp. $Y$ se nos vuelve a perder de vista, porque también el Camp "pretende salvar la vulgaridad del mundo contemporáneo". Este Camp omnímodo, omnipresente, casi divino, fetiche colosal, invocación ritual, varita mágica, va desde el "descubrimiento" de los fracasos de Bellini a los cle Agustín Lara.

El Camp es urbano, no Camp-esino. ¿Por qué no llamar a este aleteo 
divino URB? (El trio del alimón debería traducir, anotar, connotar, comentar, prolongar y epilogar The Benefactor para beneficio de todos.) El Camp es la vulgaridad sacralizada de la gente decente contra la vulgaridad neófita del pelado. Es la Banca y el baile; el antiguo Café Colón y el moderno Bar Jorongo; la casa burguesa y el Palacio de Minería (por cierto, confesamos no entender, al propósito de este Palacio, la frase de Carlos Fuentes que dice "que nos destituye el íncubo (el virreinato". Esta frase huele a Camp).

Tanto y tan importante es el Camp, que nos deja aterrados la sentencia de Carlos: "Negar nuestro Camp es una manera de empobrecernos. Asimilarlo, (es) un tesoro potencial que debe ser descubierto por un género: el de la historiografía ... pues tener sólo historia sagrada es vivir fuera de la historia.'

Esto último es, sencillamente, una verdad primaria. Hemos vivido con pura historia sagrada, sea conservadora o liberal; católica o socialista, mas ¿para no ser eso, historia sagrada, deberá ser Camp?

Hace años hubo esfuerzos que ahora ya sabemos cómo llamarlos: son Camp. Tal "En defensa de lo usado" o "La gracia de los retratos antiguos", de Fernández Ledesma, o como dice Monsiváis, de los colonialistas, desde Jenaro Estrada o Abreu Gómez (se le olvidó Riva Palacio), que ahora son Camps.

Cuando proseguimos la lectura alimonada con Monsiváis, llegamos a lo apuntado antes, de que lo Camp es "aquello tan malo que resulta bueno". De la desmesura cámpica de Fuentes llegamos a esta limitación muy cuerda, de Monsiváis. Pero no nos hagamos ilusiones: también se ponc a rodar y se hace, al bajar la pendiente, como las bolas de nieve, expresión camp que es insustituible.

Monsiváis nos amplía en varias definiciones, eso del Camp. Véalas el lector en la citada revista, la que nos interesa destacar es ésta: "Camp es una tercera corriente del gusto."

Vienen luego las atroces divisiones en el campo del Camp, como el Camp Consciente e Inconsciente; el Bajo, el Medio y el Supremo; el Alto y el Inferior o, como dice ingenua, tierna y pochamente Monsiváis: "High, middle and low Camp" (?). Parece una lección de Arqueología. Si algo es tan complicado que necesita tantos distingos, no tiene razón de ser a menos que, como en algunas ciencias, obligue ese divisionismo gradual para entenderse. Pero en una nueva sensibilidad como la Camp, ¿para qué tanto aparato? La verdad es lo que decíamos antes; de querer ser tanto, no es nada. Porque -insistimos, o más bien, 
DOI: http://dx.doi.org/10.22201/iie.18703062e.1970.39.911

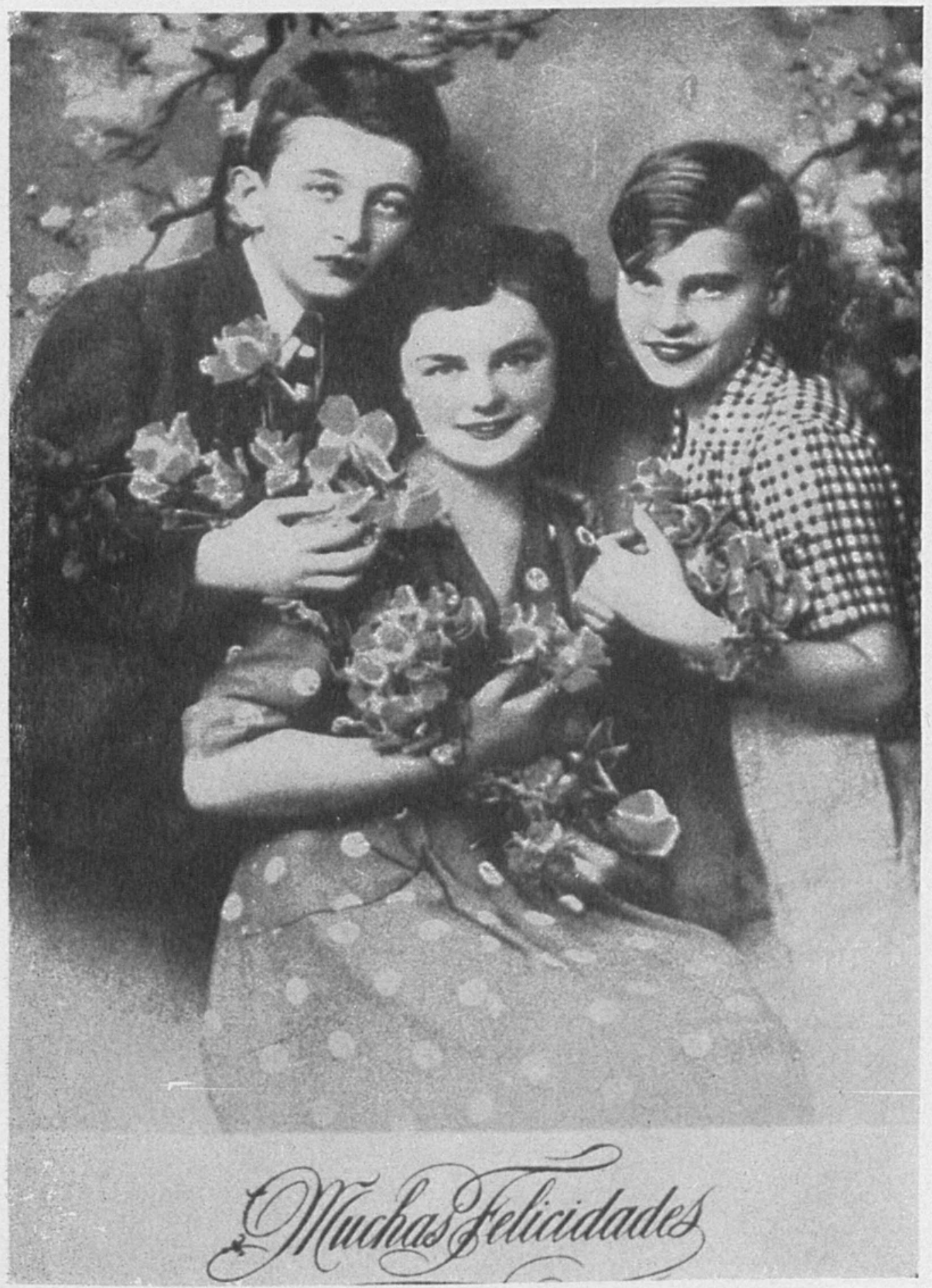

1. Delicias del hogar 
DOI: http://dx.doi.org/10.22201/iie.18703062e.1970.39.911

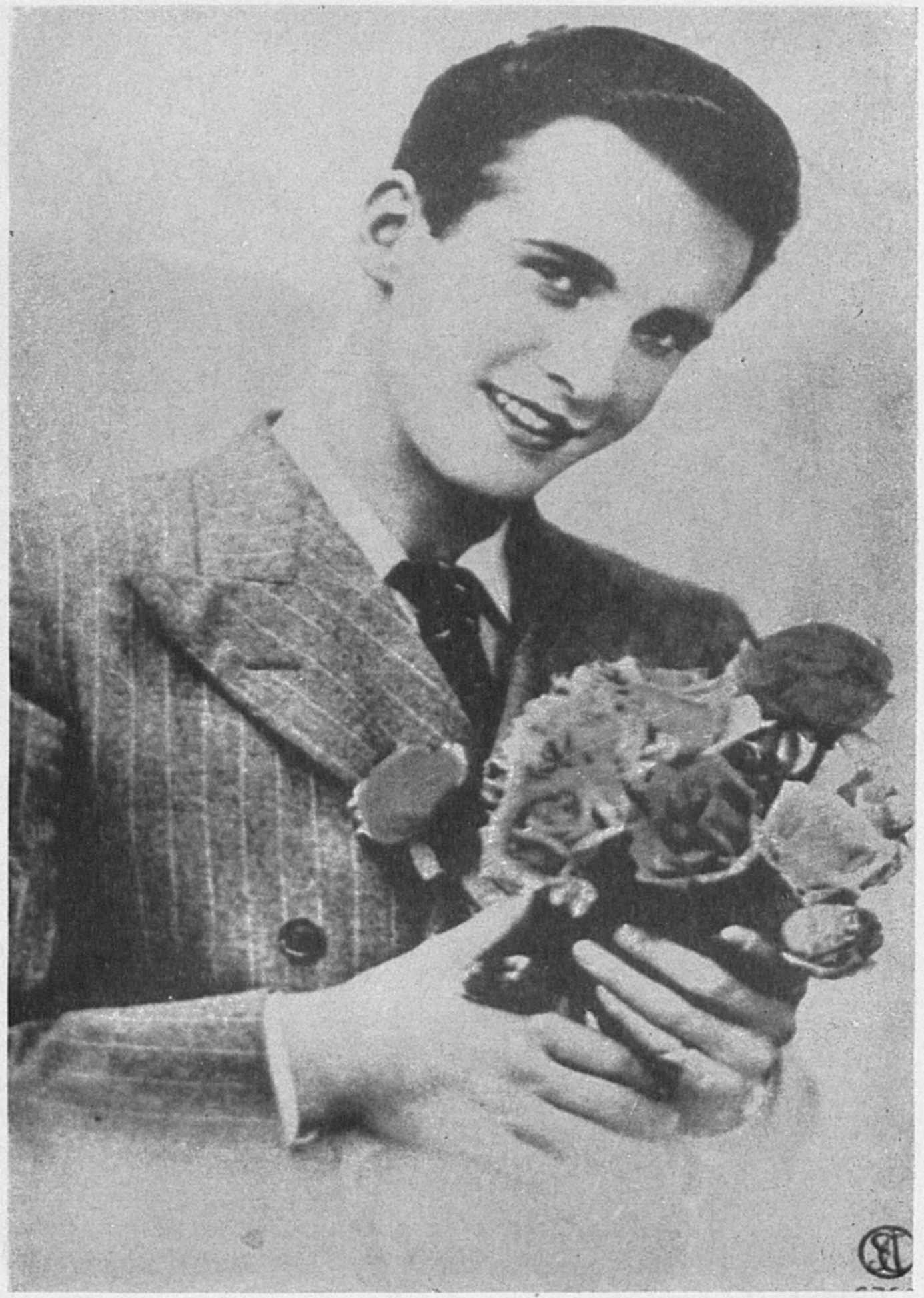


DOI: http://dx.doi.org/10.22201/iie.18703062e.1970.39.911

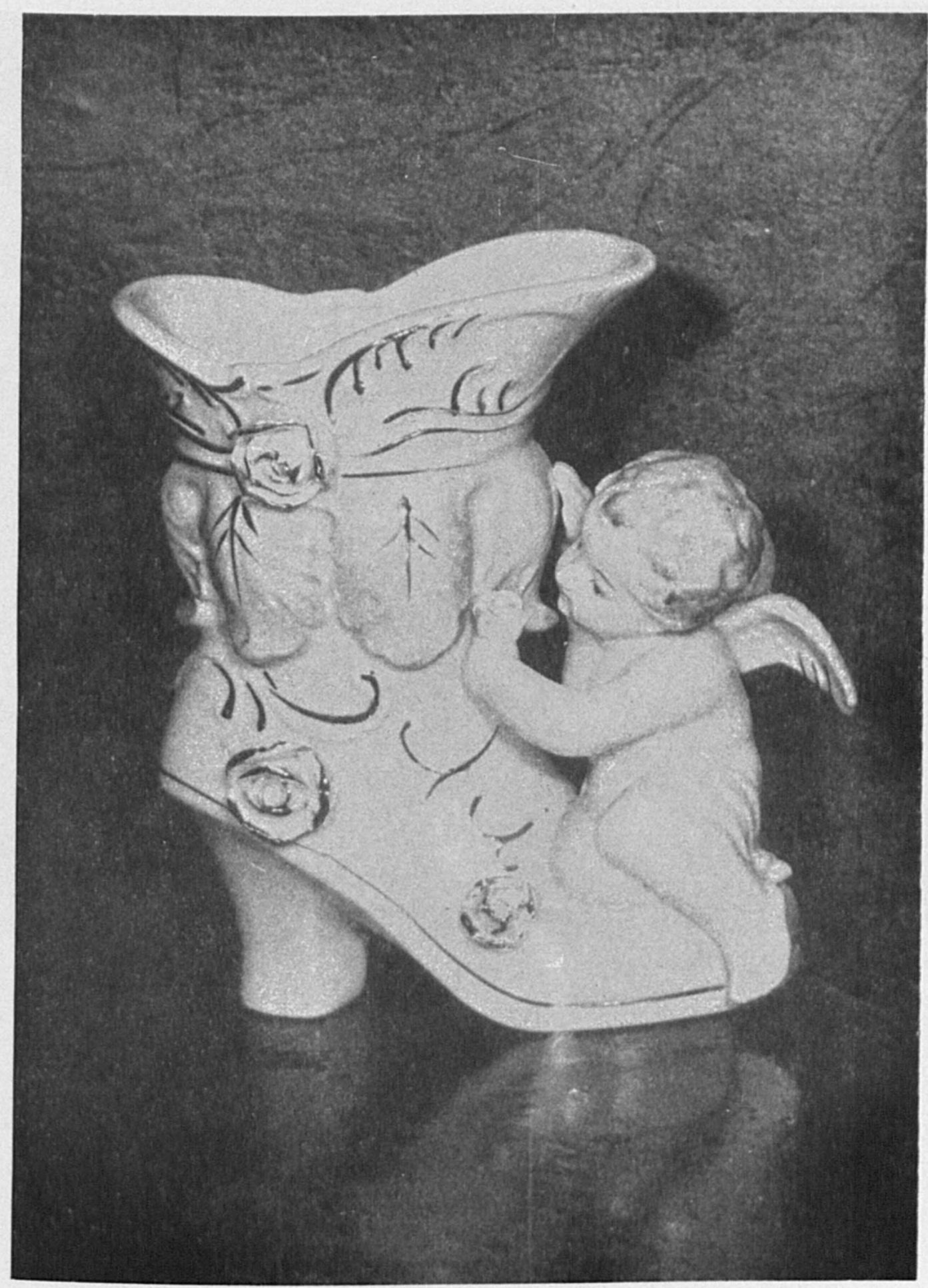

3. El querubin y la botita 


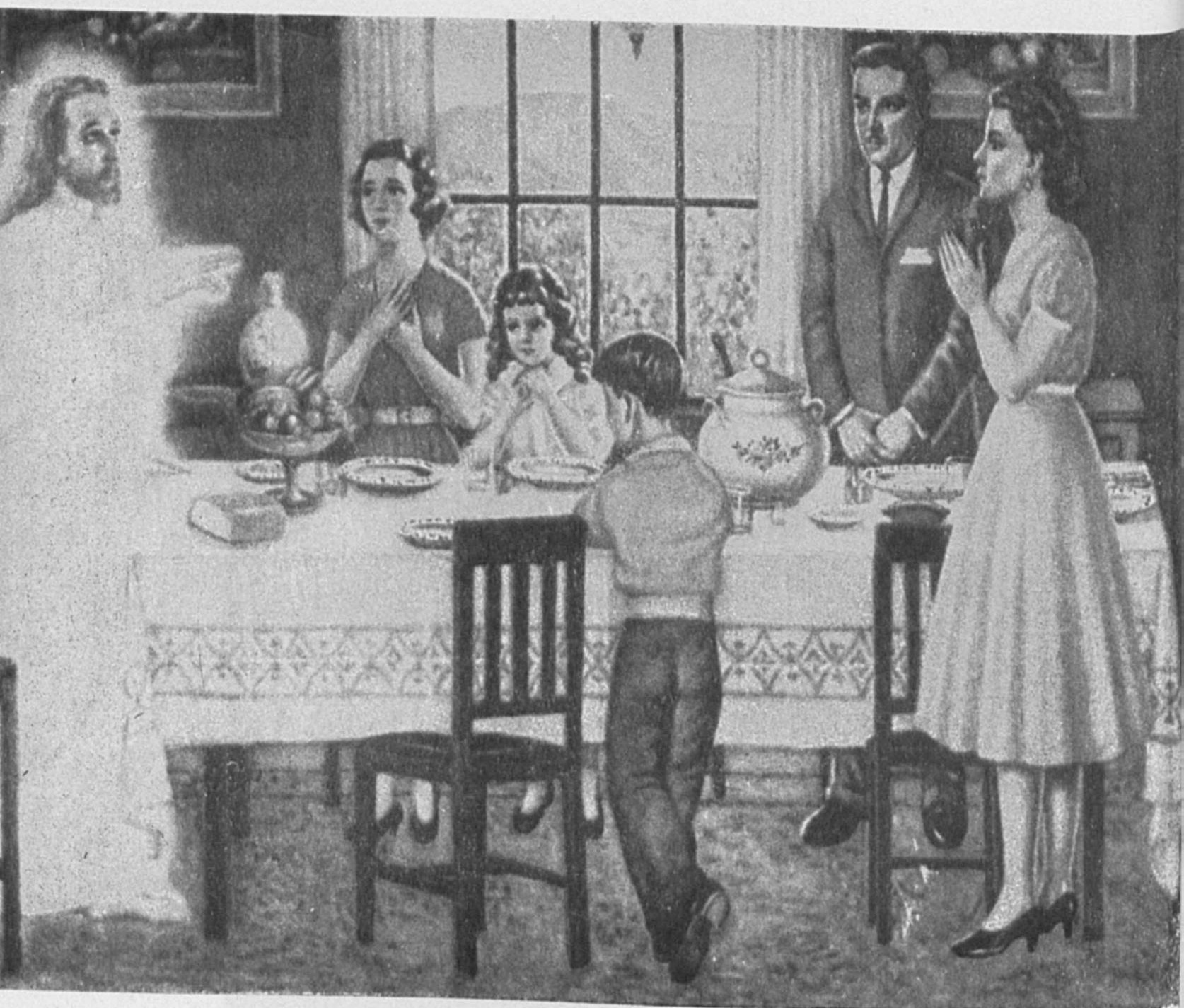

4. Unción prealimenticia 
DOI: http://dx.doi.org/10.22201/iie.18703062e.1970.39.911

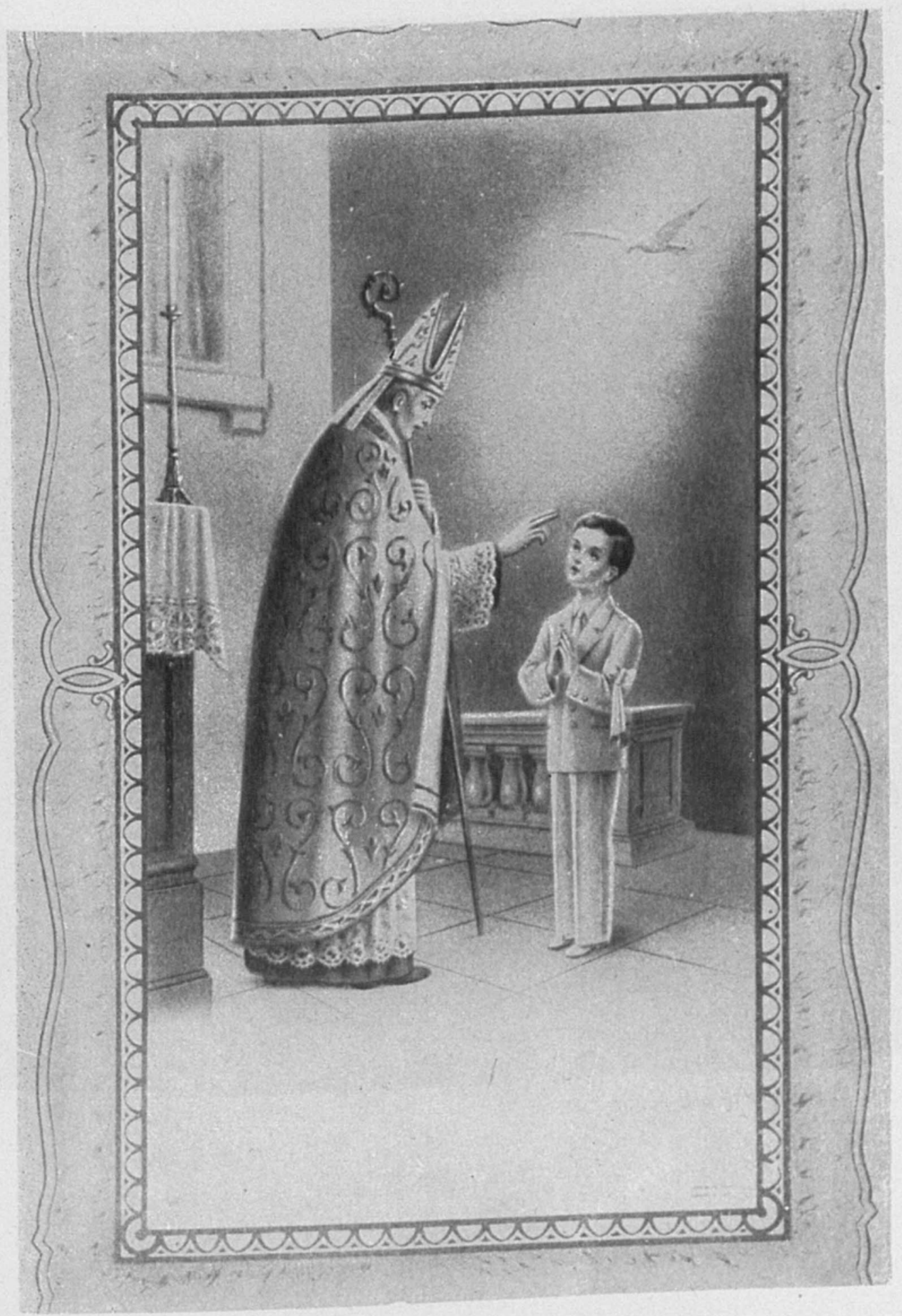

5. Que como eres, seas siempre 
DOI: http://dx.doi.org/10.22201/iie.18703062e.1970.39.911

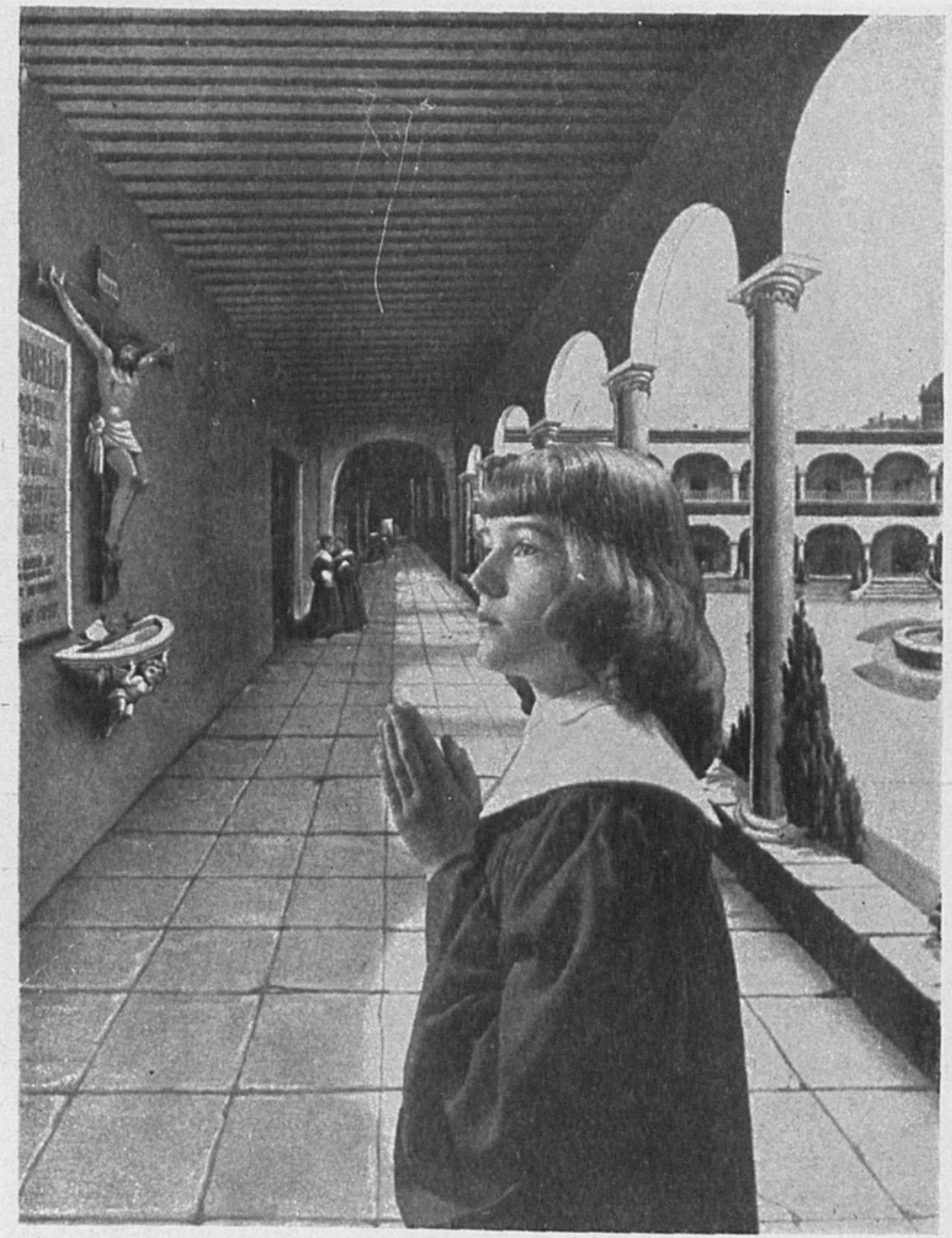

6. Siempre seré asi, Señor 


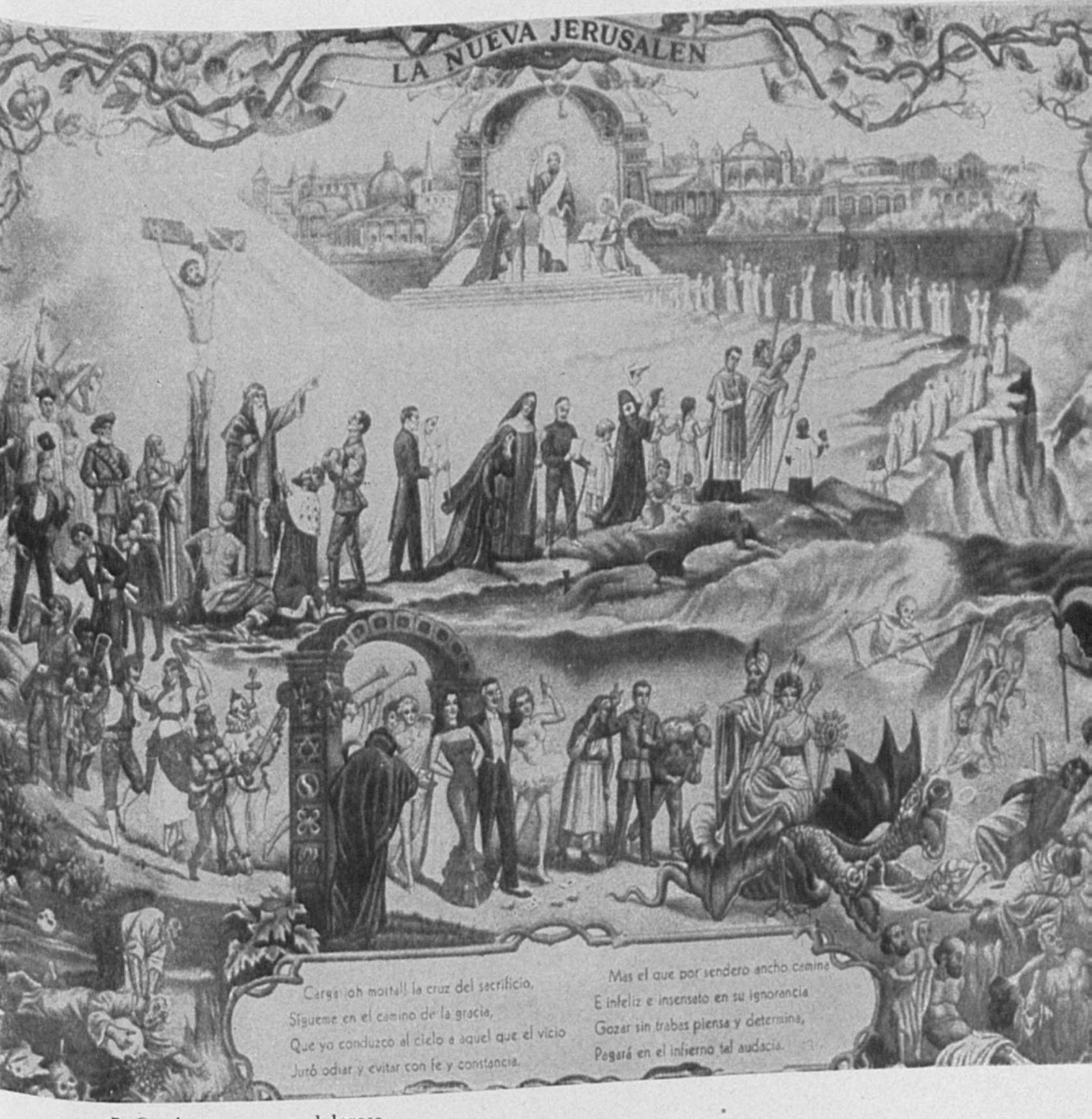

7. Caminos gozoso y doloroso 
DOI: http://dx.doi.org/10.22201/iie.18703062e.1970.39.911

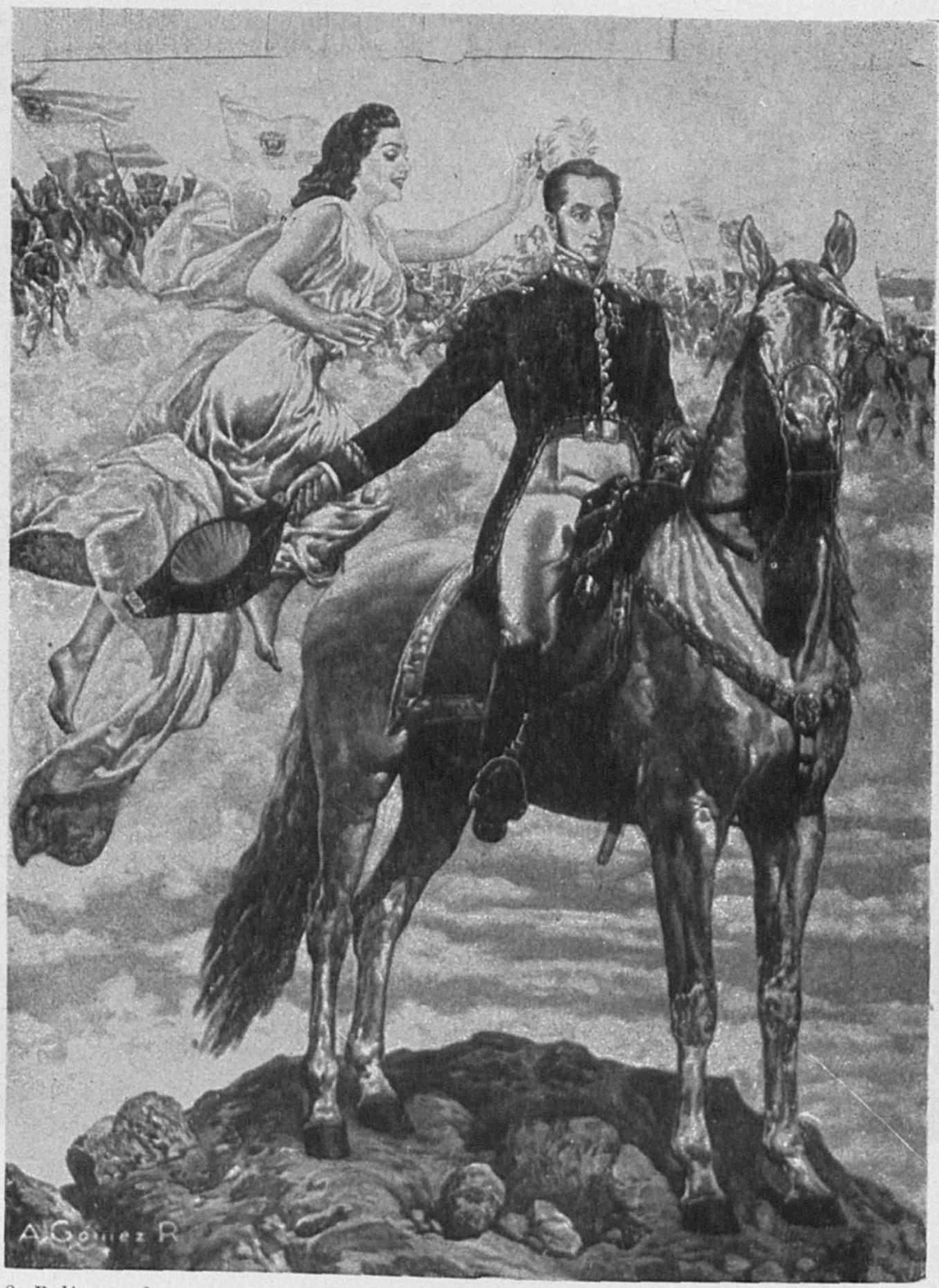

8. Bolívar y la musa 
DOI: http://dx.doi.org/10.22201/iie.18703062e.1970.39.911

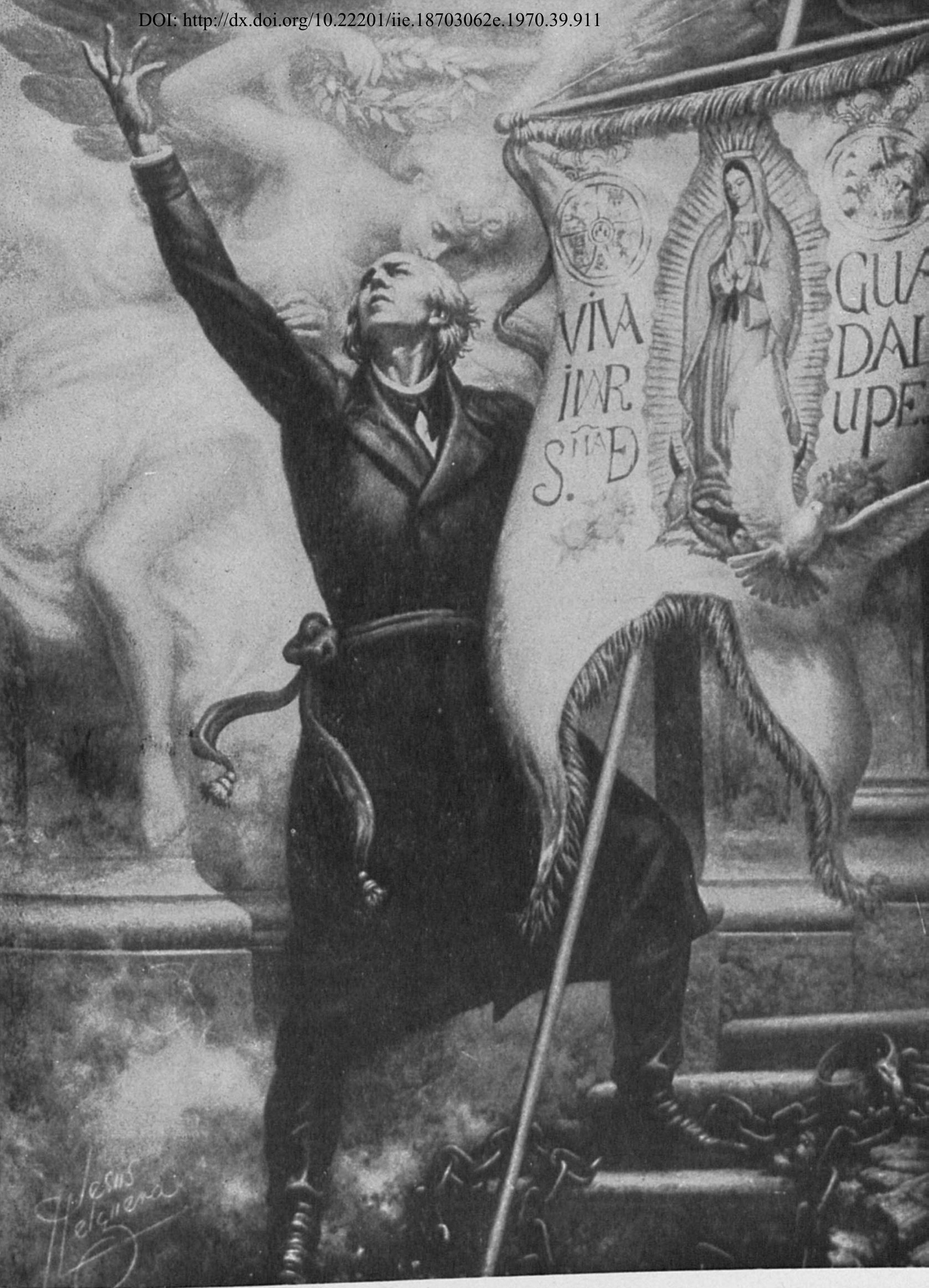




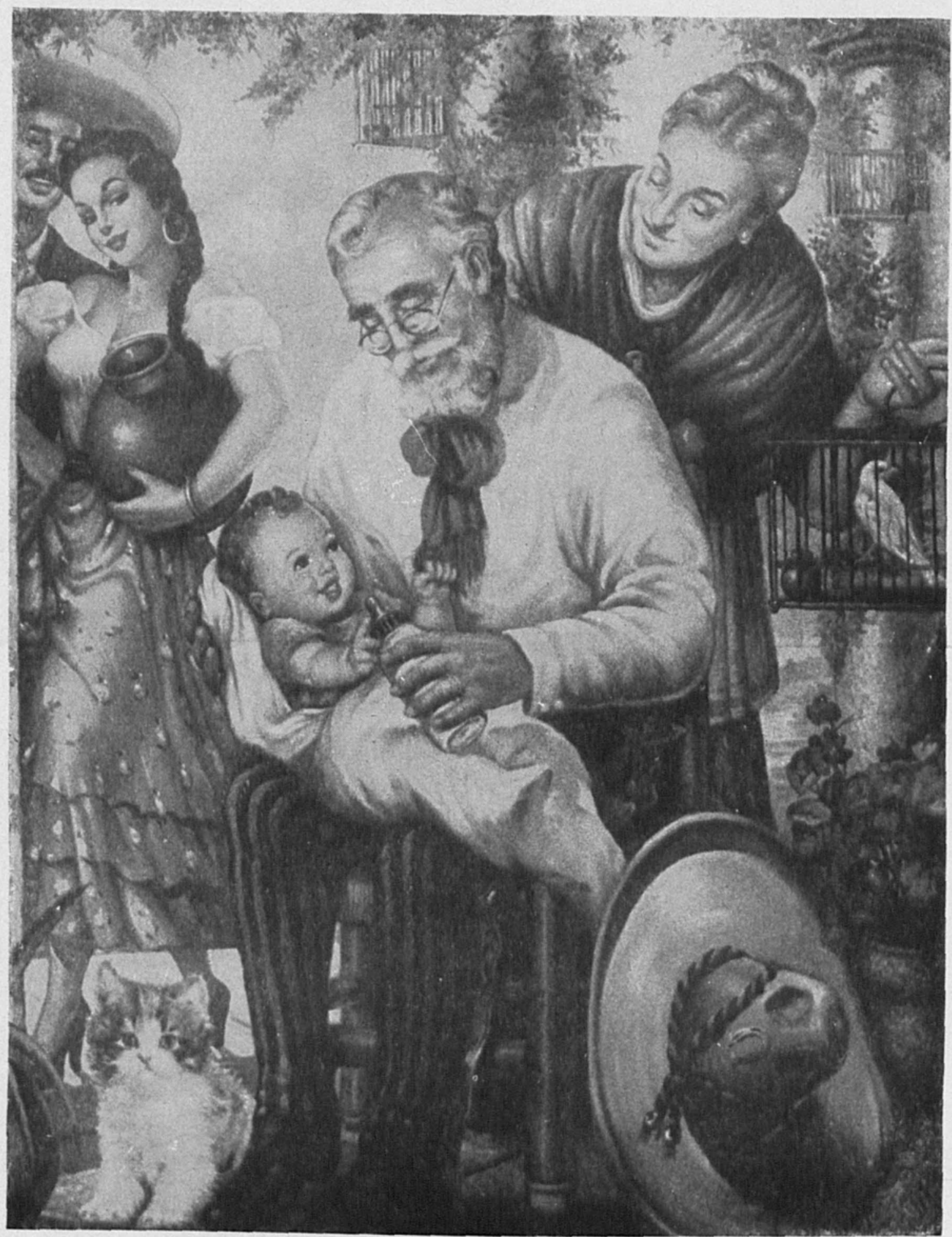

10. La familia completa y feliz, aunque falta el perıo 


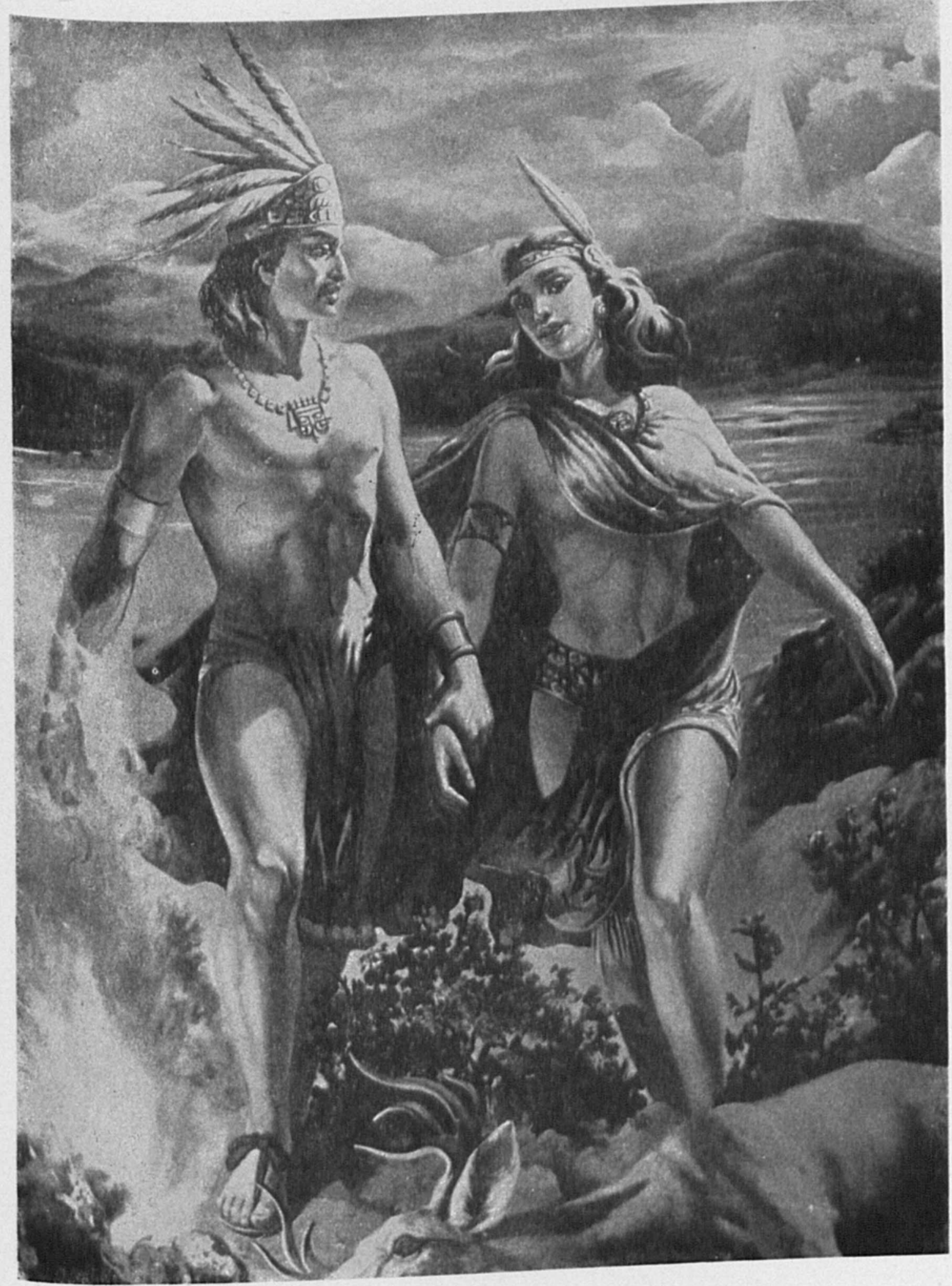

11. La bien nutrida y bella raza de bronce 
DOI: http://dx.doi.org/10.22201/iie.18703062e.1970.39.911

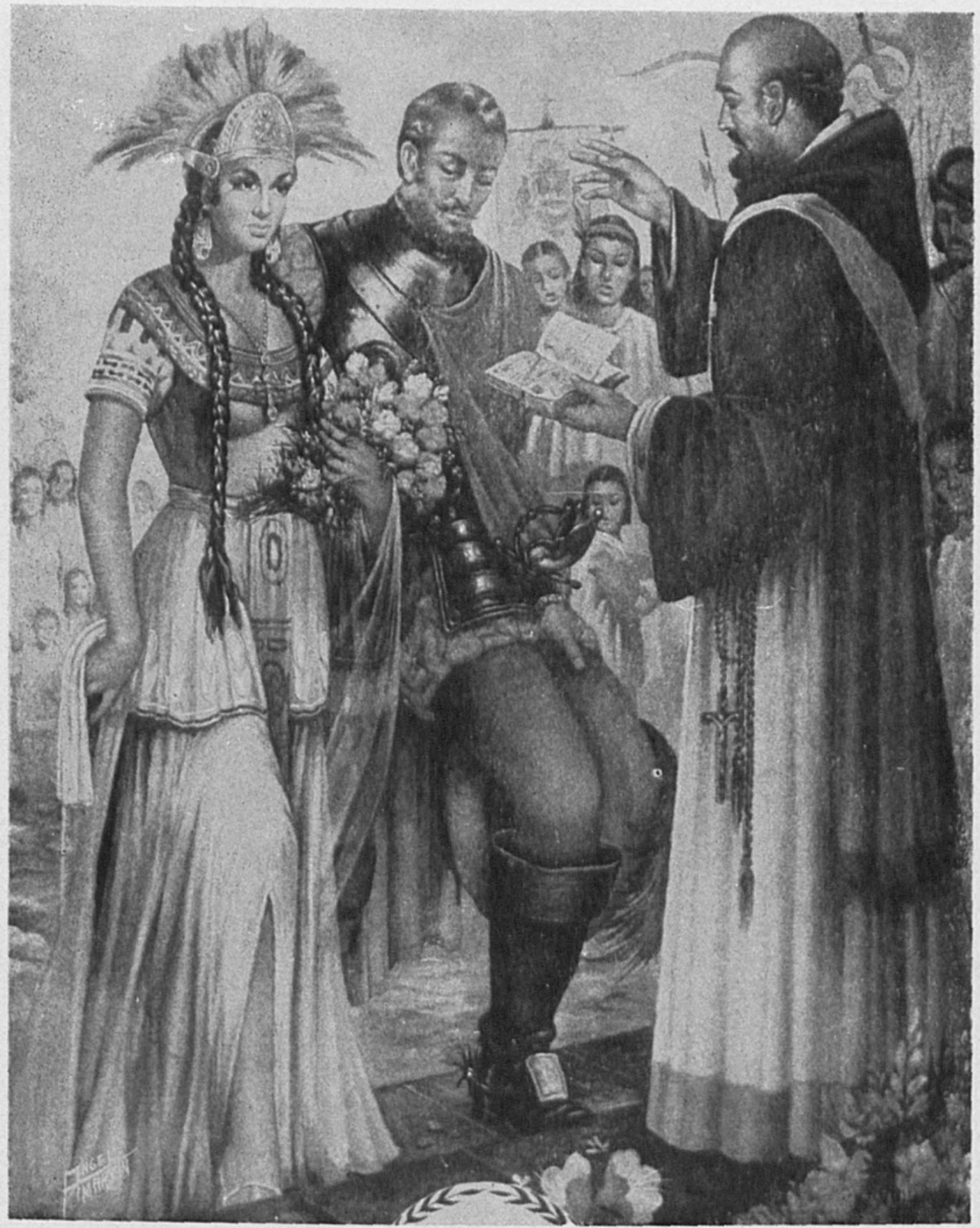

12. Dos simientes supremas para el mestizaje 
DOI: http://dx.doi.org/10.22201/iie.18703062e.1970.39.911

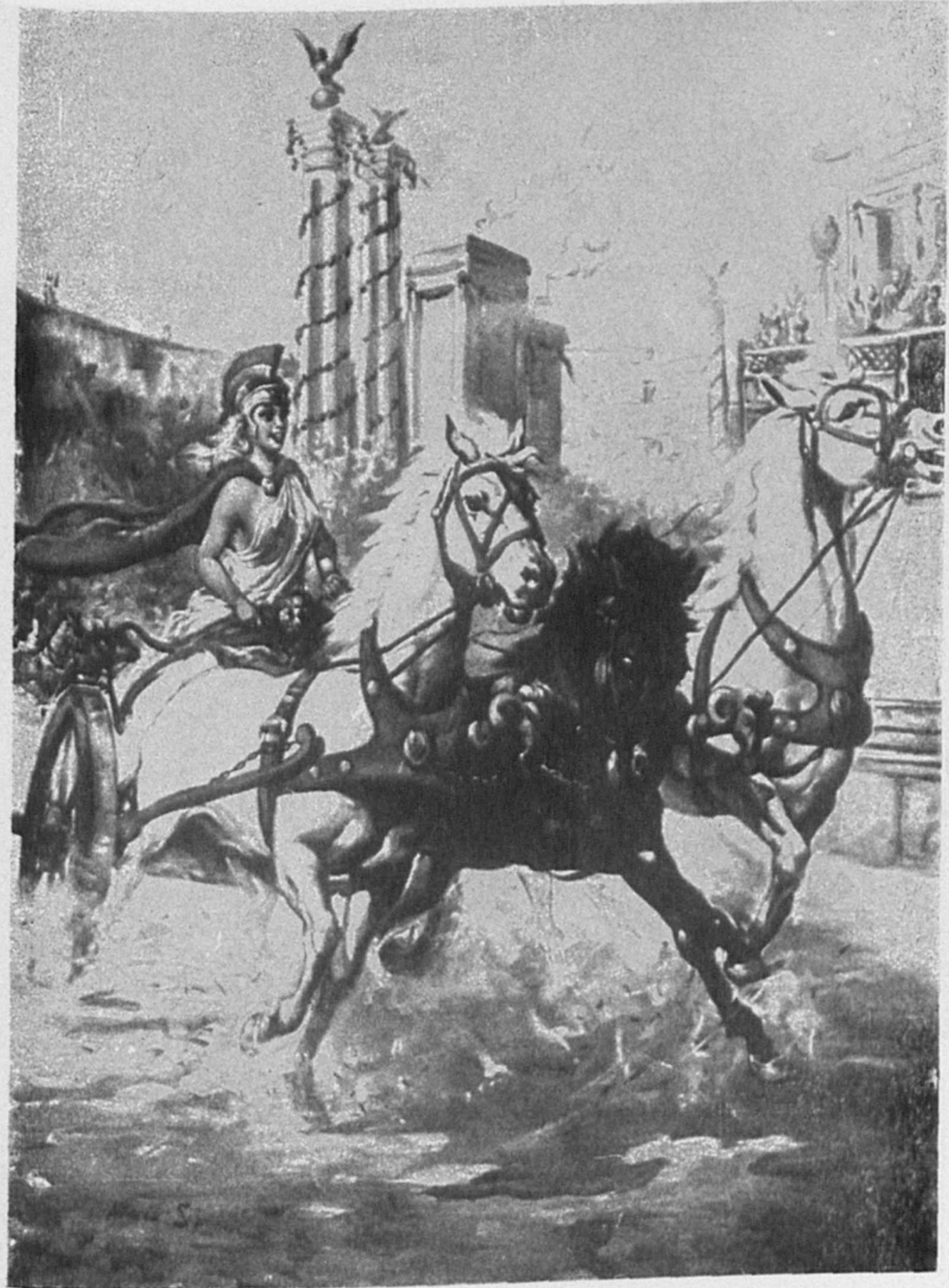

13. Doncella-soldado en el Circo romano 
DOI: http://dx.doi.org/10.22201/iie.18703062e.1970.39.911

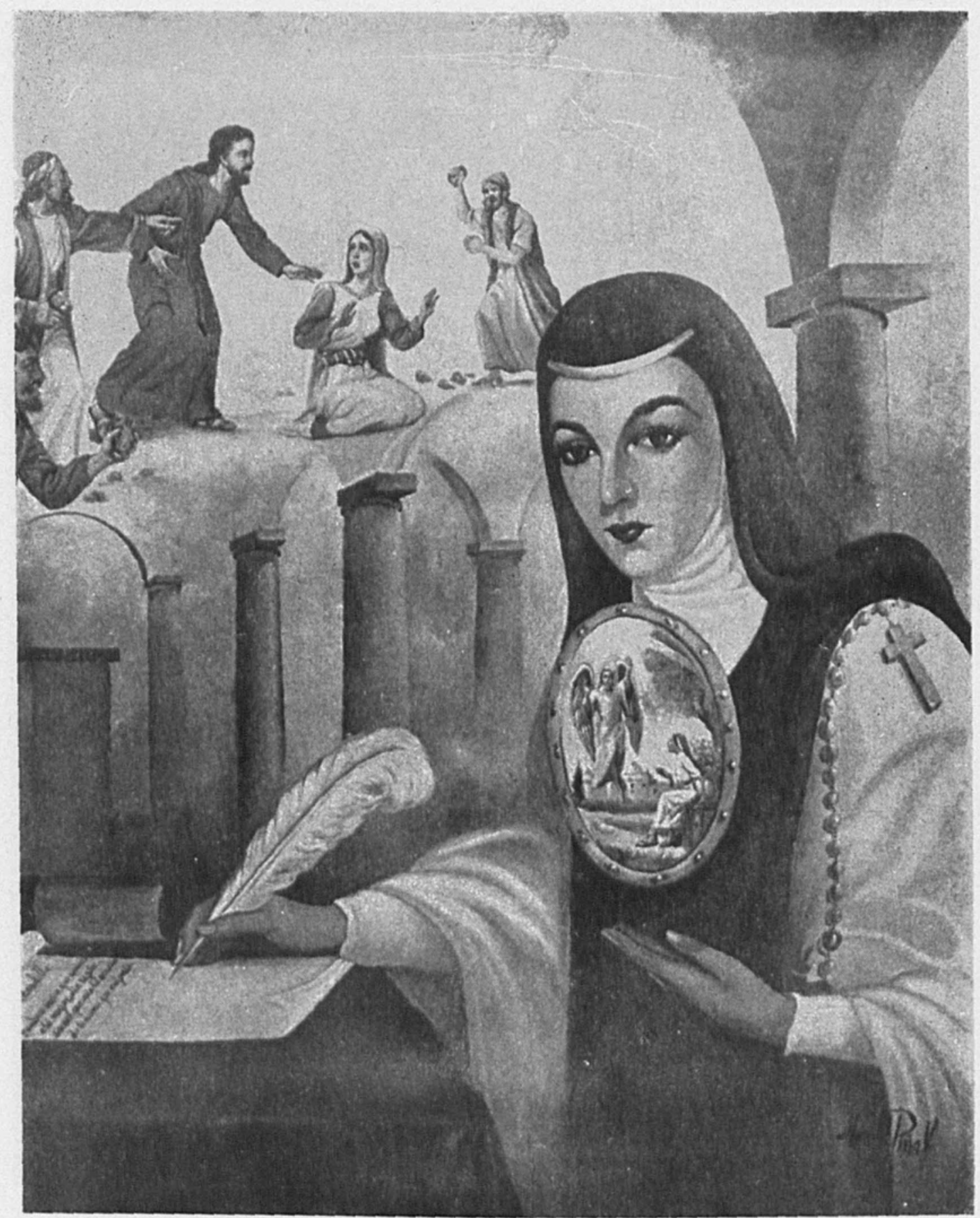

14. sor Juana maquillada como en los veintes 


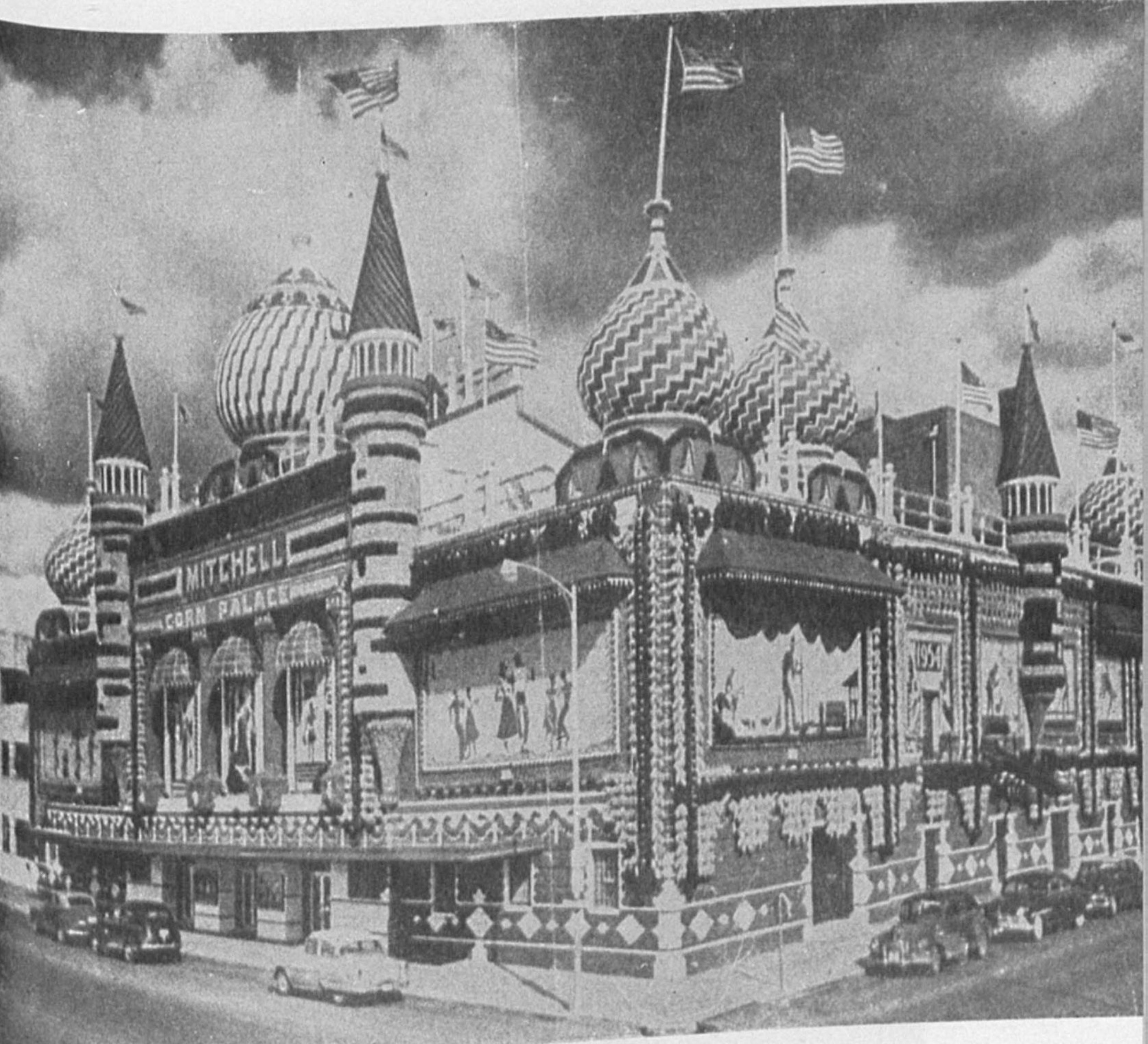

15. Edificio yanqui estilo "Estambul" 
DOI: http://dx.doi.org/10.22201/iie.18703062e.1970.39.911

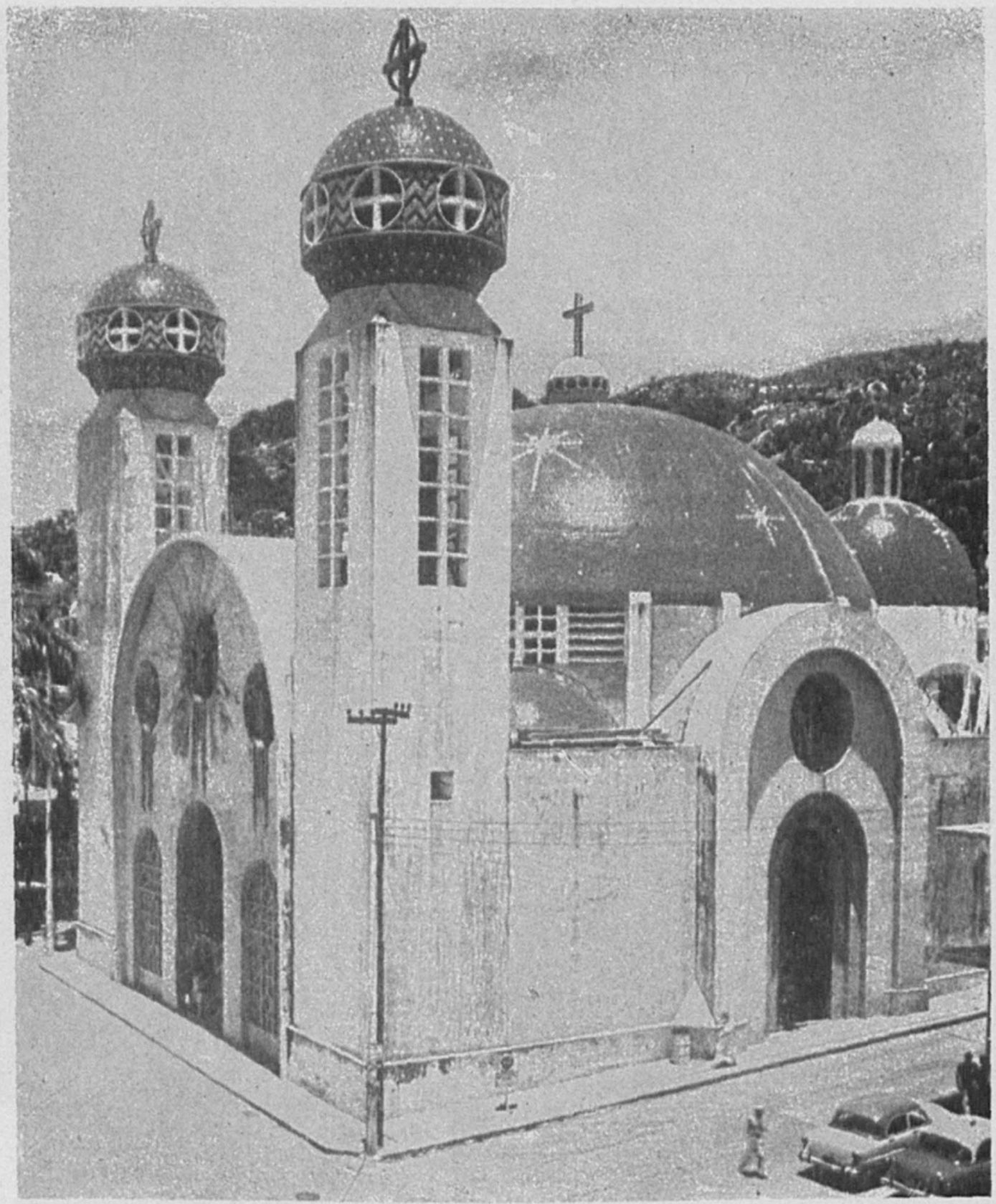

16. Catedral de Acapulco, estilo bizantino-nao-de-la-China 
insisten los tres críticos cámpicos - lo Camp es descle Bellini y Tchaikovsky hasta la Primera Guerra Mundial y... el Segundo Imperio Mexicano (?).

Otros ejemplos Camps: uno de "supremo", es una canción de Tito Guizar, otro, la propia novela de la Sontag, o Betty Davis y Cecil B. de Mille y... Greta Garbo, ¿No le tembló la morena mano a Carlos Monsiváis de poner ese nombre, así sea en el más alto estrato cámpico de lo Camp? iAh!, pero, eso sí, actores como Humphrey Bogart y Gary Cooper "nunca pueden ser considerados Camp por su calidad evidente..." Pobre de la Garbo, una Camp como Libertad Lamarque!

Siguen luego otros ejemplos del "high" o del "low" Camp, representados por peliculas malas que antes se llamaban "churros" (lo churro resulta ahora Camp) o por frases célebres de los políticos que son, simplemente, cursis. El Palacio de Bellas Artes es Camp por ser "de cuando el porfiriato se sintió París".

Y, al propósito, esa ridiculez de la palabra "porfiriato", con su olor supremo de botica, en lugar de porfirismo, ¿es ya Camp o todavia no?

Los ejemplos siguen: Andrea Palma y María Teresa Montoya y... la película Escuadrón 201.

Todo es y será Camp. Desde un obispo a los frijoles refritos, y para quien se eche a nadar en ese océano de lo Camp, no hay salvación. Camps son - del Middle Camp, eso si- la barbacoa y "los artistas manieristas y góticos..." como algunos artistas norteamericanos del cine que, además de Camps, son manieristas y góticos... (?)

No seguiremos a Monsiváis porque somos débiles. Sólo él puede atesorar en su imaginación todo lo cámpico del Camp "Iow". Y más cuando, al final, asegura que "ni en política, ni en cuestiones sociales, ni en el arte, hay todavia en México algo que sea tan malo que resulte bueno". ¿En qué quedamos?

Piazza, con su ingenio extraordinario, hace un bello revoltijo que no sabemos si ya es Camp. Nos aseguramos que estamos "más cerca", por ejemplo, del Volkswagen, que de Thomas Mann; de Drácula que de Santa Claus; de Tarzán y San Agustín, que de Ortega o Sartre o Yuri Gagarin... iY pensar que hay tanta verdad en esa página VI, junto con explosiones de bueno y de mal humor y con un "tercer" humor totalmente Camp!

$Y$ después de todo esto, ¿qué resta? Que ante el fantasma del Camp, nosotros nos quedamos con el Buen y el Mal Gusto y con lo CURSI, con esa su clira definición y sus propios objetivos que, en este caso, 
se le quiere escamotear con el Camp, pues la mayoría de los ejemplos puestos son cursis, que eso, lo Cursi, es el "tercer" gusto a que aludía Monsiváis.

Mas ahora se quiere desplazar lo Cursi, que tanto trabajo costó aclararlo, por esa niebla de lo Camp, en un plan exhibicionista, que lo único que hace es revolver y dificultar más este mundo, ya irrespirable. ${ }^{5}$

5 El 26 de mayo de 1966, el señor Castillón Bracho publicó en El Hcraldo, un articulo llamado "El Talco, el Camp y lo Cursi vienen a ser la misma cosa". Dice lo mismo que yo, pero, por supuesto, sin citarme, alardeando con ajena cabellera, diremos. 